\title{
Effects of a high-protein corn product compared with soy and canola protein sources on nutrient digestibility and production responses in mid-lactation dairy cows
}

\author{
W. E. Brown and B. J. Bradford* (1) \\ Department of Animal Sciences and Industry, Kansas State University, Manhattan 66506
}

\begin{abstract}
An experiment was conducted to assess the effects of a novel and proprietary high-protein corn product $[56 \%$ crude protein $(\mathrm{CP})]$ relative to other common sources of protein on the lactation performance of dairy cows. Twenty-four Holstein cows $(620 \pm 47.7 \mathrm{~kg}$ of body weight, $111 \pm 34 \mathrm{~d}$ in milk, $2.28 \pm 0.46$ lactations; mean \pm standard deviation) were randomly assigned to treatment sequence in a replicated $4 \times 4$ Latin square design balanced for carryover effects. Cows were individually fed 1 of 4 diets with a different protein concentrate source during each 28 -d period, including soybean meal (SBM), high-protein corn product (HPCP), soybean meal with rumen-bypass soy protein (SBMBP), and canola meal with rumen-bypass soy protein (CANBP). Diets were formulated for equal concentrations of $\mathrm{CP}$ and balanced to meet predicted lysine and methionine requirements. The SBM diet was formulated to provide $5.7 \%$ rumen-undegradable protein (RUP), whereas SBMBP and CANBP diets were formulated for $6.8 \%$ RUP to match HPCP. Data were analyzed using mixed models with the fixed effects of treatment, period, square, the interactions of treatment and period and of treatment and square, and the random effect of cow. The CANBP diet increased dry matter intake (DMI) compared with SBM and HPCP. Treatment affected milk yield, as SBMBP and CANBP increased yield compared with SBM, but HPCP decreased milk yield compared with all treatments. The HPCP diet reduced CP intake as a percent of total DMI and increased the CP content of orts, indicative of selection against HPCP. The HPCP diet also decreased apparent total-tract and $\mathrm{CP}$ digestibility, leading to less urine nitrogen excretion and greater fecal nitrogen output. The SBMBP and CANBP diets performed similarly in nearly every variable measured, except that SBMBP increased milk urea nitrogen. In conclusion, the HPCP
\end{abstract}

Received November 20, 2019

Accepted March 8, 2020.

*Corresponding author: bjbrad@msu.edu diet reduced yield of milk and milk components, likely because of reduced apparent total-tract dry matter and CP digestibility.

Key words: milk yield, dietary protein, amino acids

\section{INTRODUCTION}

Corn grain is a useful feed ingredient in lactating dairy cow diets, serving as a readily available energy substrate; however, it is low in CP (approximately 7\%). Through corn processing to produce value-added products, such as ethanol or corn sweeteners, the resulting co-products possess greater concentrations of protein and have utility as protein sources for livestock (Loy and Lundy, 2019).

Corn wet-milling and bioethanol production are 2 common processes that generate high-protein corn by-products (Loy and Lundy, 2019). Wet-milling removes the carbohydrate component through various mechanisms, resulting in the production of corn gluten feed $(25 \% \mathrm{CP})$ and corn gluten meal $(60 \% \mathrm{CP}$; Loy and Lundy, 2019). Gluten meal is a high-value product destined for feed ingredients in pet, poultry, and swine diets, whereas corn gluten feed is primarily an ingredient for ruminant diets (Loy and Lundy, 2019). Bioethanol production most commonly uses starch in grains for fermentation. The fermentation process results in spent grains known as distillers grains with solubles (DGS), which have a CP concentration of 27 to $31 \%$ (Belyea et al., 2004; Liu, 2011). Removal of fat from DGS marginally increases CP concentration (34\%; Wang et al., 2007; Morris et al., 2018), and removal of bran and germ components enhances the efficiency of ethanol production and increases CP concentration to more than 40\% (Corredor et al., 2006; Robinson et al., 2008). Distillers grains have successfully been fed to beef (Klopfenstein et al., 2008) and dairy cattle (Kelzer et al., 2009; Schingoethe et al., 2009) as a protein source, and the inclusion has become more common as ethanol production grows.

More nascent technologies are being evaluated to further add value to DGS. One concept uses sieving 
and elutriation to separate particles based upon size and density, increasing protein concentration up to $40 \%$ (Srinivasan et al., 2005). Distillers grains are an attractive feedstock for second-generation, fiber-based ethanol production because of its fiber content and ability to streamline production processes (White et al., 2008; Kim et al., 2010; Mikulski and Kłosowski, 2018 ), producing a co-product of 34 to $50 \%$ CP (Kim et al., 2008; Lundy et al., 2015). Ability to cost-effectively integrate various technologies into existing production processes will ultimately determine viability of nextgeneration ethanol plants in the future, and the feed value of resulting co-products is critical.

A new, proprietary high-protein corn product with $56 \%$ CP may be a novel option for lactating dairy cow diets. With very limited data available on livestock feeding performance using this new technology, we chose to determine its utility for replacing commonly fed protein sources in North America, such as soybean meal and canola meal, as has been done with other high-protein corn products (Nichols et al., 1998; Mulrooney et al., 2009; Christen et al., 2010). Care must be taken when feeding different protein sources, because not all protein sources have equal value, due to differences in their AA profiles relative to the AA requirements of the animal. The 2 most limiting AA in the lactating dairy cow are typically considered to be lysine and methionine (NRC, 2001). Lysine concentration as a percentage of CP is greatest in soybean meal and least in corn products, whereas methionine concentration is greatest in canola meal and least in soybean meal (Maxin et al., 2013). When diets are formulated for similar CP concentration, the lack of methionine or lysine may inhibit performance, depending on diet characteristics (Donkin et al., 1989; Nichols et al., 1998; Wang et al., 2010). Therefore, the objective of this experiment was to assess milk production and nitrogen digestibility responses of high-producing Holstein cows following replacement of common protein sources with a novel high-protein corn product, while maintaining consistent predicted supply of metabolizable methionine and lysine across diets. We hypothesized that the novel high-protein corn product would perform similarly to other common protein sources fed in dairy diets.

\section{MATERIALS AND METHODS}

\section{Animals, Design, and Diets}

Twenty-four multiparous Holstein cows near peak lactation (111 \pm 34 DIM, $2.3 \pm 0.46$ lactations, mean \pm SD) from the Kansas State University Dairy Teaching and Research Center (Manhattan, KS) were randomly assigned to treatment sequence using a random number sequence generator (Microsoft Excel, Microsoft Corporation, Redmond, WA) in a replicated $4 \times 4$ Latin square design balanced for carryover effects. Power analysis conducted before study initiation determined that 24 animals were sufficient to detect a difference in mean milk yield of $2.7 \mathrm{~kg} / \mathrm{d}(\alpha=0.05, \beta=0.16$; Kononoff and Hanford, 2006). Cows were housed in a tiestall barn. All experimental procedures were conducted with approval from the Institutional Animal Care and Use Committee at Kansas State University. Treatment periods were $28 \mathrm{~d}$, with $25 \mathrm{~d}$ for diet adaptation and $3 \mathrm{~d}$ for sample collection. Feeding of treatments began in October 2018 and continued through January 2019. Cows were fed twice daily at 0600 and $1900 \mathrm{~h}$ and milked 3 times daily at 0400, 1100, and $1800 \mathrm{~h}$.

Cows were individually fed 1 of 4 diets ad libitum, with different protein concentrate sources, during each 28-d period, including soybean meal (SBM), high-protein corn product (HPCP; $56.1 \% \mathrm{CP}$ ), soybean meal with bypass protein (SBMBP), and canola meal with bypass protein (CANBP). Soybean meal and canola meal were chosen as treatments for comparison because they are typical protein sources fed on North American farms and can be used as standard benchmarks for comparison with the novel HPCP. A base TMR was delivered to each cow, with treatment top-dressed and mixed by hand at each feeding. Diets were formulated (NDS Professional, RUM\&N Sas, Reggio Emilia, Italy) to meet nutrient requirements of a $629-\mathrm{kg}$ cow producing $52 \mathrm{~kg} / \mathrm{d}$ milk with $3.6 \%$ fat and $3.1 \%$ protein. Diets were formulated for equal concentrations of $\mathrm{CP}$ and balanced to meet metabolizable lysine $(79.5 \mathrm{~g} / \mathrm{d})$ and methionine $(225 \mathrm{~g} / \mathrm{d})$ requirements. Amino acid composition of the HPCP (Official Method 982.30; AOAC International, 2016) is shown in Table 1, whereas library values were used for all other common feed ingredients (NRC, 2001). The SBM diet was formulated to provide $5.7 \%$ RUP, and SBMBP and CANBP diets were formulated for $6.8 \%$ RUP to match HPCP. The HPCP RUP was estimated in commercial laboratories with a combination of 16-h incubation in situ (Calsamiglia and Stern, 1995) and in vitro (Ross et al., 2013), and intestinal digestibility was determined with the modifications of Ross et al. (2013). The diets were formulated to provide equal concentrations of forage NDF and starch. Nutrient composition and ingredients are shown in Table 2.

One cow was removed from the experiment during the second collection period due to hemorrhagic diarrhea and was subsequently replaced for the remaining 2 periods. Period 2 data were not retained from this cow. Another cow was dried off in 1 quarter following an udder injury during period 3. Data were analyzed both with and without inclusion of this cow post-dry off, and 
Table 1. Amino acid profile of a proprietary high-protein corn product (HPCP) fed to lactating Holstein cows

\begin{tabular}{lc}
\hline Item & HPCP \\
\hline CP, \% & 56.1 \\
AA, g/kg of DM & \\
Ala & 31.7 \\
Arg & 12.9 \\
Asp & 27.6 \\
Glu & 67.5 \\
His & 9.1 \\
Ile & 17.7 \\
Lys & 8.7 \\
Met & 8.4 \\
Phe & 20.9 \\
Pro & 33.2 \\
Ser & 18.2 \\
Thr & 16.0 \\
Tyr & 18.3 \\
Val & 21.9 \\
\hline
\end{tabular}

it was determined that this did not affect evidence of significance for any treatment, so data were included in the final analysis. This resulted in analysis of data from
95 of 96 total collection period observations, with only 23 of 24 observations for HPCP, due to the removal of 1 cow during the collection period.

\section{Data and Sample Collection and Analysis}

Feed offered and refused for each cow was recorded daily during the final $3 \mathrm{~d}$ of each treatment period. Water intake was recorded daily. Samples of the TMR, concentrate treatment mixes, and individual feed ingredients were collected daily and composited over the collection period for analysis. Feed refusals were frozen and later composited over the collection period for each cow and dried in a $55^{\circ} \mathrm{C}$ forced-air oven. All feed samples were sent to Dairyland Laboratories Inc. (Arcadia, WI) for nutrient analysis (Table 3) using wet chemistry. Dry matter was determined by drying at $60^{\circ} \mathrm{C}$ until moisture was less than $6 \%$, and then at $105^{\circ} \mathrm{C}$ for 3 h (Shreve et al., 2006). Neutral detergent fiber was determined using an amylase-treated method (method 2002.04; AOAC International, 2016). Indigestible NDF

Table 2. Ingredients and nutrient composition of experimental diets fed to lactating Holstein cows supplemented with a protein source from either soybean meal (SBM), a high-protein corn product (HPCP), soybean meal with bypass protein (SBMBP), or canola meal with bypass protein (CANBP)

\begin{tabular}{|c|c|c|c|c|}
\hline \multirow[b]{2}{*}{ Item, $\%$ of DM } & \multicolumn{4}{|c|}{ Diet } \\
\hline & SBM & HPCP & SBMBP & CANBP \\
\hline \multicolumn{5}{|l|}{ Dietary ingredients } \\
\hline Corn silage & 34.5 & 34.5 & 34.5 & 34.5 \\
\hline Alfalfa hay & 19.5 & 19.5 & 19.5 & 19.5 \\
\hline Soybean meal, $47.5 \%$ solvent extracted & 10.7 & — & 3.9 & - \\
\hline High-protein corn product $^{1}$ & - & 9.4 & - & - \\
\hline Canola meal, $37 \%$ solvent extracted & - & - & - & 8.9 \\
\hline Expeller soybean meal $^{2}$ & - & - & 8.0 & 4.7 \\
\hline Ground corn grain & 22.6 & 22.6 & 22.6 & 22.6 \\
\hline Soybean hulls & 7.8 & 8.8 & 6.8 & 5.0 \\
\hline Ca salts of long-chain fatty acids ${ }^{3}$ & 0.75 & 0.75 & 0.75 & 0.75 \\
\hline Lysine hydrochloride $^{4}$ & 0.32 & 0.68 & 0.11 & 0.26 \\
\hline $\mathrm{HMBi}^{5}$ & 0.24 & 0.17 & 0.17 & 0.15 \\
\hline Micronutrient premix $^{6}$ & 3.6 & 3.7 & 3.6 & 3.6 \\
\hline \multicolumn{5}{|l|}{ Diet nutrient composition } \\
\hline $\mathrm{DM}, \%$ as fed & 52.8 & 52.6 & 52.9 & 52.9 \\
\hline $\mathrm{CP}$ & 16.8 & 16.8 & 16.8 & 16.8 \\
\hline aNDFom $^{7}$ & 30.2 & 30.3 & 30.0 & 30.3 \\
\hline Starch & 22.5 & 22.7 & 22.6 & 22.7 \\
\hline Ether extract & 4.3 & 4.9 & 4.5 & 4.7 \\
\hline Ash & 8.2 & 8.1 & 8.2 & 8.3 \\
\hline
\end{tabular}

${ }^{1}$ Proprietary high-protein corn product.

${ }^{2}$ SoyPlus (Landus Cooperative, Ames, IA).

${ }^{3}$ Megalac-R (Arm and Hammer Animal Nutrition, Princeton, NJ).

${ }^{4}$ Lysine hydrochloride, lecithin, and hydrogenated vegetable oil, AjiPro-L (Ajinimoto Animal Nutrition North America, Chicago, IL).

${ }^{5}$ Isopropyl ester of 2-hydroxy-4-methylthio butanoic acid, MetaSmart (Adisseo Inc., Antony, France).

${ }^{6}$ The premix consists of $30.5 \%$ limestone, $20.8 \%$ sodium bicarbonate, $30.5 \%$ Kruse lactation premix (International Nutrition, Omaha, NE), $4.40 \%$ trace mineral salt, $4.42 \%$ white salt, $7.08 \%$ magnesium oxide, $4.42 \%$ vitamin E premix, 0.69\% Zinpro 4-plex (Zinpro Corporation, Eden Prairie, MN), 0.35\% Zinpro 120 (Zinpro Corporation), and $0.19 \%$ Rumensin 90 (Elanco Animal Health, Greenfield, IN).

${ }^{7}$ aNDFom $=$ ash-free, amylase-treated NDF. 
Table 3. Nutrient composition of major feed ingredients fed to lactating Holstein cows

\begin{tabular}{|c|c|c|c|c|c|c|c|}
\hline Component, $\%$ of DM & \multicolumn{7}{|c|}{ Feed ingredient ${ }^{1}$} \\
\hline DM, \% as fed & 29.1 & 92.7 & 90.6 & 91.7 & 87.5 & 92.4 & 92.1 \\
\hline aNDFom $^{3}$ & 47.0 & 33.5 & 16.3 & 16.5 & 17.1 & 15.7 & 17.1 \\
\hline Starch & 16.6 & 2.3 & 49.5 & 12.8 & 13.6 & 13.5 & 13.9 \\
\hline Ether extract ${ }^{4}$ & 4.2 & 2.2 & 3.9 & 7.7 & 10.9 & 8.9 & 9.7 \\
\hline
\end{tabular}

${ }^{1} \mathrm{SBM}=$ soybean meal top-dress; HPCP $=$ high-protein corn product top-dress; SBMBP = soybean meal + bypass protein top-dress; CANBP $=$ canola meal + bypass protein top-dress.

${ }^{2}$ Protein top-dress treatments included $16.4 \%$ dry ground corn, $4.3 \%$ calcium salts of long-chain fatty acids, soy hulls, AjiPro-L (Ajinomoto Animal Nutrition North America Inc., Chicago, IL), and MetaSmart (Adisseo Inc., Antony, France).

${ }^{3}$ aNDFom $=$ ash-free, amylase-treated NDF.

${ }^{4}$ Protein top-dress treatments were subjected to an additional acid hydrolysis step due to inclusion of calcium salts of fatty acids.

was determined in fermentation flasks according to Goering and Van Soest (1970) after 240-h fermentation (Raffrenato et al., 2018), and residual NDF was determined as described above. Crude protein was determined via analysis for nitrogen with AOAC method 990.03 (AOAC International, 2016), and acid-detergent insoluble crude protein (ADICP) was determined on grain treatments by collecting ADF residue on filter paper using method 973.18 (AOAC International, 2016) and analyzing for nitrogen to determine CP. Crude fat was determined with the use of diethyl ether on a Foss Soxtec 2047 (Foss North America, Eden Prairie, MN; method 920.39, AOAC International, 2016), and grain treatments containing calcium salts of fatty acids were subjected to an additional acid hydrolysis step using the SoxCap 2047 (Foss North America). Ash concentration was determined using AOAC method 942.05 (AOAC International, 2016). Orts samples were analyzed for 240-h indigestible NDF and CP using the same methods.

Milk samples were collected at every milking during the collection period. Samples were analyzed for fat, true protein, lactose, nonfat solids, and MUN using infrared spectroscopy (Bentley FTS; Bentley Instruments Inc., Chaska, MN), and somatic cells were counted using a flow cytometer (Bentley FCM; Bentley Instruments Inc.) at MQT Labs (Kansas City, MO). The 3.5\% FCM was calculated as FCM $=($ milk $\mathrm{kg} \times 0.432)+($ fat $\mathrm{kg}$ $\times 16.216)$, and $\mathrm{ECM}=(0.327 \times$ milk kg $)+(12.95 \times$ fat $\mathrm{kg})+(7.65 \times$ protein $\mathrm{kg})$.

Fecal grab samples were collected for determination of total-tract digestibility every $9 \mathrm{~h}$ during the 3 -d collection period to represent every $3 \mathrm{~h}$ over a 24 -h period. Samples were frozen immediately and were later thawed and composited by cow on an equal volume basis and dried in a $55^{\circ} \mathrm{C}$ forced-air oven. Dried samples were later ground through a 6-mm screen for analysis by Dairyland Laboratories. Indigestible NDF was deter- mined in fermentation flasks according to Goering and Van Soest (1970) after 240-h fermentation (Raffrenato et al., 2018), and residual NDF was determined as outlined above. Crude protein was determined by analysis for nitrogen using AOAC method 990.03. Total-tract digestibility was calculated using 240-h indigestible NDFom as an internal marker to estimate total fecal output, with digestibility determined by the ratio of nutrient concentration in the feces and diet consumed (Cochran and Galyean, 1994).

Urine samples were collected via vulva stimulation every $9 \mathrm{~h}$ during the 3 -d collection period to represent every $3 \mathrm{~h}$ over a 24 -h period. Urine was diluted 1:3 in $0.15 \mathrm{~N} \mathrm{H}_{2} \mathrm{SO}_{4}$ to achieve $\mathrm{pH}<2$ and then frozen at $-20^{\circ} \mathrm{C}$. After each collection period, samples were thawed and composited by cow and period on an equal volume basis. Urine was analyzed in duplicate for creatinine using alkaline picrate (Cayman Chemical, Ann Arbor, MI), and total urine output was estimated assuming a constant creatinine excretion rate of $29 \mathrm{mg} / \mathrm{kg}$ of BW (Valadares et al., 1999). Urine N concentration was determined in duplicate using a LECO TruMac Nitrogen Analyzer (LECO Corporation, St. Joseph, MO). Total daily urinary $\mathrm{N}$ excretion was calculated using the estimated volume of urine excretion from creatinine analysis.

Cows were weighed individually on the initial $2 \mathrm{~d}$ of the study and during the final $2 \mathrm{~d}$ of each collection period to determine body weight change. Body condition score was recorded for each cow by 2 trained investigators blinded to treatment at the initiation of the study and at the end of each period to determine body condition change.

\section{Statistical Analysis}

During period 1, some individual milk weight data were missing due to an equipment recording error. To 
account for missing data in an unbiased manner, milk yield, component yield, and composition data were analyzed by individual milking over the 3 -d collection period. Data were analyzed using JMP (version 13.0, SAS Institute Inc., Cary, NC) according to the following statistical models. The model for milk production data was

$$
\begin{aligned}
\mathrm{Y}_{\mathrm{ijkln}}= & \mu+\mathrm{T}_{\mathrm{i}}+\mathrm{P}_{\mathrm{j}}+\mathrm{S}_{\mathrm{k}}+\mathrm{T}_{\mathrm{i}} \times \mathrm{P}_{\mathrm{j}}+\mathrm{T}_{\mathrm{i}} \times \mathrm{S}_{\mathrm{k}} \\
& +\mathrm{M}_{\mathrm{l}}\left(\mathrm{P}_{\mathrm{j}}\right)+\mathrm{C}_{\mathrm{n}}+\mathrm{C}_{\mathrm{n}} \times \mathrm{P}_{\mathrm{j}}+\mathrm{e}_{\mathrm{ijk} \mathrm{kln}},
\end{aligned}
$$

where $\mu$ is the overall treatment mean, $T_{i}$ is the fixed effect of treatment ( $\mathrm{i}=1$ to 4 ), $\mathrm{P}_{\mathrm{j}}$ is the fixed effect of period ( $\mathrm{j}=1$ to 4$), \mathrm{S}_{\mathrm{k}}$ is the fixed effect of square $(\mathrm{k}=1$ to 6$), \mathrm{T}_{\mathrm{i}} \times \mathrm{P}_{\mathrm{j}}$ is the interaction of treatment and period, $T_{i} \times S_{k}$ is the interaction of treatment and square, $\mathrm{M}_{1}\left(\mathrm{P}_{\mathrm{j}}\right)$ is the random effect of milking time nested within period ( $1=1$ to 9$), \mathrm{C}_{\mathrm{n}}$ is the random effect of cow ( $n=1$ to 24$), C_{n} \times P_{j}$ is the interaction of cow and period, and $\mathrm{e}_{\mathrm{ijkln}}$ is the residual error.

The model for feed and water intake, feed efficiency, nitrogen balance and output, digestibility, body weight, and body condition score data was as follows:

$$
\begin{aligned}
Y_{i j k n}=\mu+ & T_{i}+P_{j}+S_{k}+T_{i} \times P_{j}+T_{i} \\
& \times S_{k}+C_{n}+e_{i j k n},
\end{aligned}
$$

where $\mu$ is the overall treatment mean, $T_{i}$ is the fixed effect of treatment ( $\mathrm{i}=1$ to 4 ), $\mathrm{P}_{\mathrm{j}}$ is the fixed effect of period ( $\mathrm{j}=1$ to 4$), \mathrm{S}_{\mathrm{k}}$ is the fixed effect of square $(\mathrm{k}=1$ to 6$), \mathrm{T}_{\mathrm{i}} \times \mathrm{P}_{\mathrm{j}}$ is the interaction of treatment and period, $T_{i} \times S_{k}$ is the interaction of treatment and square, $C_{n}$ is the random effect of cow ( $n=1$ to 24 ), and $\mathrm{e}_{\mathrm{ijkln}}$ is the residual error.

Best linear unbiased predictors for cow $\times$ period milk yields were used to determine daily means for FCM and milk nitrogen excretion to calculate feed efficiency and nitrogen balance. Denominator degrees of freedom were checked to verify the lack of pseudoreplication in all models.
Data were evaluated for normality, and data points with studentized residuals $>4$ or $<-4$ were considered outliers and removed from analysis. Interactions for fixed effects with $P>0.20$ were removed from the model. Differences between treatments were declared significant when $P<0.05$ according to Tukey's range test.

\section{RESULTS}

DMI

Treatment affected DMI, with CANBP increasing DMI compared with SBM and HPCP (Table 4; $P<$ 0.01), and HPCP increased orts CP concentration compared with all other treatments (Table 4; $P<0.001$ ). These 2 factors altered $\mathrm{N}$ intake, as both SBMBP and CANBP increased $\mathrm{N}$ intake compared with HPCP (Table 4; $P<0.001$ ). HPCP reduced $\mathrm{CP}$ intake as a proportion of total DMI compared with all other treatments (Table $4 ; P<0.001$ ). The HPCP and SBMBP diets increased water consumption relative to CANBP (Table $4 ; P<0.001$ ).

\section{Milk Yield and Components}

Treatment affected milk yield (Table 5; $P<0.001$ ), as cows fed SBM produced less milk than those fed SBMBP and CANBP but more than those fed HPCP. We found no evidence of differences in milk fat concentration (Table 5; $P=0.86$ ), but diet affected milk fat yield (Table $5 ; P<0.001$ ). We found that CANBP increased milk fat yield compared with SBM and HPCP, and SBMBP increased fat yield compared with HPCP. The SBM diet increased milk protein concentration compared with HPCP (Table 5; $P<0.01$ ), and HPCP decreased protein yield compared with all other treatments (Table 5; $P<0.01$ ). Analysis revealed no evidence of treatment effects on milk lactose concentration (Table 5; $P=0.59$ ), but HPCP decreased lactose yield

\begin{tabular}{|c|c|c|c|c|c|c|}
\hline Item & \multicolumn{4}{|c|}{ Diet } & SEM & $P$-value \\
\hline DMI, kg/d & $27.6^{\mathrm{b}}$ & $27.3^{\mathrm{b}}$ & $28.1^{\mathrm{ab}}$ & $28.9^{\mathrm{a}}$ & 0.46 & $<0.01$ \\
\hline $\mathrm{N}$ intake, $\mathrm{g} / \mathrm{d}$ & $753^{\mathrm{ab}}$ & $722^{\mathrm{b}}$ & $762^{\mathrm{a}}$ & $783^{\mathrm{a}}$ & 12.7 & $<0.001$ \\
\hline CP intake, $\%$ of total DMI & $17.0^{\mathrm{a}}$ & $16.5^{\mathrm{b}}$ & $17.0^{\mathrm{a}}$ & $16.9^{\mathrm{a}}$ & 0.04 & $<0.001$ \\
\hline Water intake, $\mathrm{L} / \mathrm{d}$ & $108.5^{\mathrm{ab}}$ & $110.4^{\mathrm{a}}$ & $111.9^{\mathrm{a}}$ & $102.8^{\mathrm{b}}$ & 3.0 & $<0.001$ \\
\hline
\end{tabular}
$(P<0.001)$. The SBM and SBMBP diets increased

Table 4. Dry matter and water intake of lactating Holstein cows supplemented with a protein source consisting of soybean meal (SBM), a highprotein corn product (HPCP), soybean meal with bypass protein (SBMBP), or canola meal with bypass protein (CANBP)

${ }^{\mathrm{a}, \mathrm{b}}$ Means with different superscripts within a row are significantly different by Tukey's honestly significant difference $(P<0.05)$. 
Table 5. Production of milk and milk components and milk nitrogen secretion of lactating Holstein cows supplemented with a protein source consisting of soybean meal (SBM), a high-protein corn product (HPCP), soybean meal with bypass protein (SBMBP), or canola meal with bypass protein (CANBP)

\begin{tabular}{|c|c|c|c|c|c|c|}
\hline Item & \multicolumn{4}{|c|}{ Diet } & SEM & $P$-value \\
\hline Milk, kg/d & $39.9^{\mathrm{b}}$ & $37.4^{\mathrm{c}}$ & $42.0^{\mathrm{a}}$ & $42.4^{\mathrm{a}}$ & 1.79 & $<0.001$ \\
\hline Protein, $\%$ & $3.08^{\mathrm{a}}$ & $3.00^{\mathrm{b}}$ & $3.03^{\mathrm{ab}}$ & $3.04^{\mathrm{ab}}$ & 0.04 & $<0.01$ \\
\hline Lactose, \% & 4.81 & 4.84 & 4.84 & 4.84 & 0.03 & 0.59 \\
\hline MUN, mg/dL & $11.7^{\mathrm{a}}$ & $10.0^{\mathrm{c}}$ & $11.6^{\mathrm{a}}$ & $10.8^{\mathrm{b}}$ & 0.34 & $<0.01$ \\
\hline Protein, kg/d & $1.21^{\mathrm{a}}$ & $1.12^{\mathrm{b}}$ & $1.27^{\mathrm{a}}$ & $1.28^{\mathrm{a}}$ & 0.05 & $<0.001$ \\
\hline Lactose, $\mathrm{kg} / \mathrm{d}$ & $1.92^{\mathrm{b}}$ & $1.80^{\mathrm{c}}$ & $2.04^{\mathrm{a}}$ & $2.06^{\mathrm{a}}$ & 0.08 & $<0.001$ \\
\hline $\mathrm{SNF}, \mathrm{kg} / \mathrm{d}$ & $3.41^{\mathrm{b}}$ & $3.17^{\mathrm{c}}$ & $3.58^{\mathrm{ab}}$ & $3.62^{\mathrm{a}}$ & 0.15 & $<0.001$ \\
\hline FCM, kg/d & $41.5^{\mathrm{b}}$ & $39.4^{\mathrm{b}}$ & $43.8^{\mathrm{a}}$ & $44.4^{\mathrm{a}}$ & 1.50 & $<0.001$ \\
\hline $\mathrm{ECM}, \mathrm{kg} / \mathrm{d}$ & $41.7^{\mathrm{b}}$ & $39.3^{\mathrm{c}}$ & $43.9^{\mathrm{ab}}$ & $44.4^{\mathrm{a}}$ & 1.54 & $<0.001$ \\
\hline Feed efficiency, $\mathrm{kg}$ of FCM/kg of DMI & $1.52^{\mathrm{ab}}$ & $1.49^{\mathrm{b}}$ & $1.56^{\mathrm{a}}$ & $1.52^{\mathrm{ab}}$ & 0.03 & 0.06 \\
\hline Milk nitrogen secretion, $\mathrm{g} / \mathrm{d}$ & $198^{\mathrm{a}}$ & $180^{\mathrm{b}}$ & $204^{\mathrm{a}}$ & $207^{\mathrm{a}}$ & 8.2 & $<0.001$ \\
\hline
\end{tabular}

${ }^{\mathrm{a}-\mathrm{c}}$ Means with different superscripts within a row are significantly different by Tukey's honestly significant difference $(P<0.05)$.

${ }^{1}$ Data were $\log _{10}$-transformed for analysis, and means were reverse transformed.

MUN compared with CANBP (Table $5 ; P<0.01$ ), but HPCP decreased MUN. We discovered no evidence of a treatment effect on SCC (Table 5; $P=0.41$ ). Feeding HPCP reduced milk nitrogen secretion compared with all other treatments (Table 5; $P<0.001$ )

Cows fed SBMBP and CANBP produced more FCM compared with those fed SBM and HPCP (Table 5; $P<0.001$ ). Treatment also affected ECM (Table 5; $P<0.001)$ : CANBP increased ECM yield compared with SBM and HPCP. Cows fed HPCP produced the least ECM. A tendency for a treatment effect on feed efficiency occurred (FCM:DMI; Table 5; $P=0.06$ );
SBMBP increased feed efficiency compared with HPCP $(P<0.05$, Tukey's HSD $)$.

\section{Digestibility and Nitrogen Balance}

The CANBP diet increased urinary $\mathrm{N}$ concentration compared with HPCP (Table 6; $P<0.01$ ). We found no evidence of a treatment effect on urine output (Table 6 ; $P=0.15$ ); however, HPCP reduced urinary $\mathrm{N}$ excretion compared with SBM and CANBP (Table 6, $P=0.02$ ).

Compared with SBMBP and CANBP, SBM reduced fecal N concentration and HPCP increased fecal N con-

Table 6. Urine and feces nitrogen excretion, whole-body nitrogen balance, apparent total-tract DM and CP digestibility, and BW and BCS change of lactating Holstein cows supplemented with protein source consisting of soybean meal (SBM), a high-protein corn product (HPCP), soybean meal with bypass protein (SBMBP), or canola meal with bypass protein (CANBP)

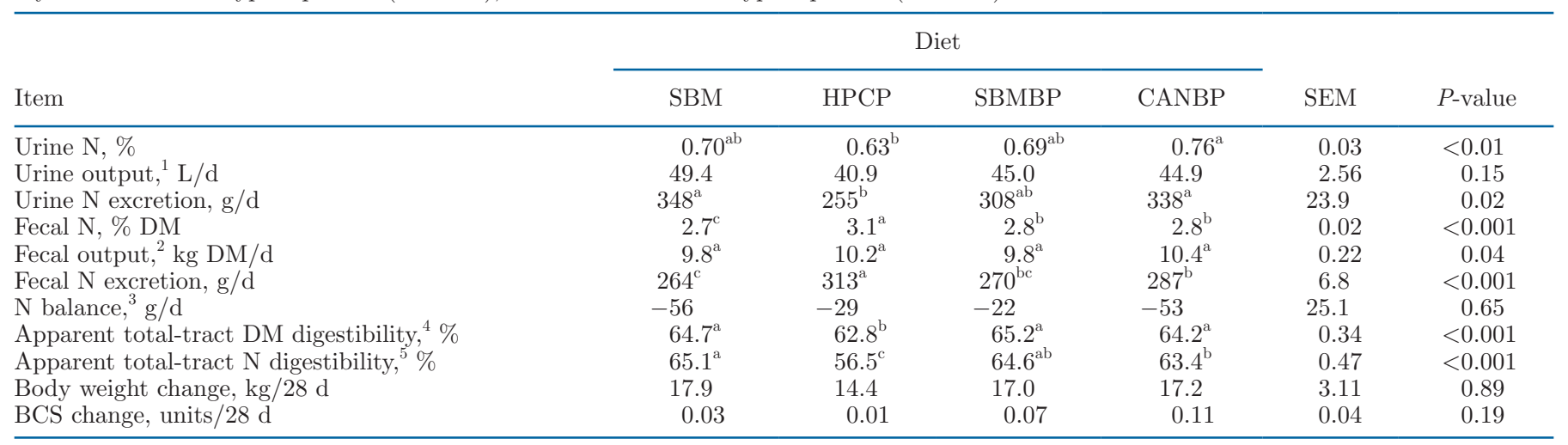

\footnotetext{
${ }^{\mathrm{a}-\mathrm{c}}$ Means with different superscripts within a row are significantly different by Tukey's honestly significant difference $(P<0.05)$.

${ }^{1}$ Estimated assuming a constant creatinine excretion rate of $29 \mathrm{mg} / \mathrm{kg}$ of BW (Valadares et al., 1999).

${ }^{2}$ Estimated using 240-h indigestible NDF as an internal marker (Cochran and Galyean, 1994).

${ }^{3}$ Nitrogen balance $=\mathrm{N}$ intake $-($ milk $\mathrm{N}+$ urine $\mathrm{N}+$ fecal $\mathrm{N})$.

${ }^{4}$ Apparent total-tract digestibility $=100-100 \times(\mathrm{g}$ of fecal DM $\div \mathrm{g}$ of DM consumed $)$; Cochran and Galyean (1994).
}

${ }^{5}$ Apparent total-tract N digestibility $=100-100 \times(\mathrm{g}$ of fecal $\mathrm{N} \div \mathrm{g}$ of N consumed); Cochran and Galyean (1994). 
centration (Table $6 ; P<0.001$ ). Results of an $F$-test for fecal DM output were significant $(P=0.04)$; however, the conservative Tukey's HSD did not identify any significant contrast among treatments. Cows fed HPCP excreted more $\mathrm{N}$ than all other treatments (Table $6 ; P$ $<0.001$ ), and SBM decreased fecal $\mathrm{N}$ excretion compared with CANBP.

The HPCP diet reduced total-tract DM digestibility compared with all other treatments (Table $6 ; P<$ 0.001). Treatment also affected apparent total-tract $\mathrm{N}$ digestibility, as CANBP reduced digestibility compared with SBM but increased digestibility compared with HPCP (Table 6; $P<0.001$ ). We discovered no evidence of a treatment effect on $\mathrm{N}$ balance (Table $6 ; P=0.65$ ), body weight change $(P=0.89)$, nor BCS change $(P=$ $0.19)$.

\section{Treatment Nutrient Profile}

Post-hoc analysis of top-dress premixes was carried out to confirm that formulated nutrient profiles were achieved and to evaluate whether Maillard product formation may have contributed to HPCP responses. The results revealed a dramatically greater concentration of ADICP in the HPCP mix (7.9\%) compared with all other treatments ( $1.0 \%$ or less; data not shown).

\section{DISCUSSION}

The reduction of milk production among cows fed the HPCP diet appears to result from 2 factors: first, through the reduction of $\mathrm{CP}$ intake, and second, through the reduction in apparent total-tract $\mathrm{CP}$ digestibility. The cows fed HPCP had greater orts CP concentration and lower CP intake as a percentage of total DMI compared with the other treatments, suggesting that they sorted against the HPCP. Although most mature dairy cattle sort during lactation to obtain a more energy-dense diet (Miller-Cushon and DeVries, 2017), instances arise where cattle sort against protein concentrate sources due to palatability (Lardy and Kerley, 1994). It may be that the production of HPCP imparted a flavor or odor prompting the cows to select against the HPCP, as corn coproducts are typically highly palatable (Klopfenstein et al., 2008).

The bypass protein was added to the SBMBP and CANBP diets in this study to assess the HPCP on an equal-RUP basis, which was not possible with the SBM diet alone. In the present study, the HPCP diet decreased total-tract apparent $\mathrm{N}$ digestibility and urinary $\mathrm{N}$ excretion, and increased fecal $\mathrm{N}$ excretion, compared with the other treatments. In other studies, increasing RUP decreased apparent CP digestibility in mid-lactation cows, and cows fed diets with greater
RUP had reduced urinary $\mathrm{N}$ excretion and elevated fecal $\mathrm{N}$ excretion despite similar $\mathrm{N}$ intake (Brito and Broderick, 2007). This suggests that the ruminal digestibility of the HPCP in our study was perhaps less than anticipated, leading to the greater fecal $\mathrm{N}$ excretion and lesser urinary $\mathrm{N}$ excretion. The results from Brito and Broderick (2007) suggest that the lesser fecal $\mathrm{N}$ excretion of the SBM diet compared with all other treatments was likely due to the lesser RUP content of that diet. Additionally, Noftsger and St-Pierre (2003) reported a decrease in milk production from cows fed less-digestible RUP sources at the same dietary CP concentration, which aligns with the lesser milk production of HPCP compared with the other treatments in this study.

One explanation for the reduction in digestibility of $\mathrm{CP}$ that led to reduced milk production for HPCP compared with other treatments may be the formation of Maillard products during drying. Excessive heating of feed products is known to increase ADICP concentration in distillers grains, which is positively correlated with fecal N concentration (van Soest and Mason, 1991). Previous HPCP protein digestibility analysis provided by the suppliers using in situ (Ross et al., 2013) and in vitro methods (Krishnamoorthy et al., 1983) conducted in commercial laboratories reported $52.9 \%$ RUP. Content of ADICP was unknown. Nonetheless, post-hoc analysis of the protein source top-dresses in the present study clearly demonstrated elevated ADICP for the HPCP top-dress. The HPCP top-dress was 7.9\% ADICP, whereas the other top-dress protein treatments were less than $1.0 \%$ ADICP (data not shown). This coincides with the high fecal $\mathrm{N}$ excretion for those cows and the dark color of the product (Figure 1), consistent with Maillard product formation (Urriola et al., 2013). Similarly, bench-top production of a high-protein corn product during the initial concept development of cellulosic ethanol fermentation using distillers grains resulted in heat damage and decreased lysine and methionine concentration compared with protein from distillers grains (Kim et al., 2008). Traditional heating and cooking of the grain before the dry-milling process for ethanol production resulted in RUP concentrations (55\%) similar to those of a high-protein DGS from fractionation of corn before the fermentation process, but the high-protein DGS had greater total-tract digestibility (Kelzer et al., 2010). In contrast, a high-protein corn product $(39.1 \%)$ from cellulosic fermentation of distillers grains decreased DM and $\mathrm{OM}$ digestibility compared with traditional distillers grains $(34.1 \% \mathrm{CP}$; Lundy et al., 2015). It is unclear whether the reduction in protein availability for HPCP is due to the drying process for long-term storage or to another upstream process, so further investigation of those processes is 


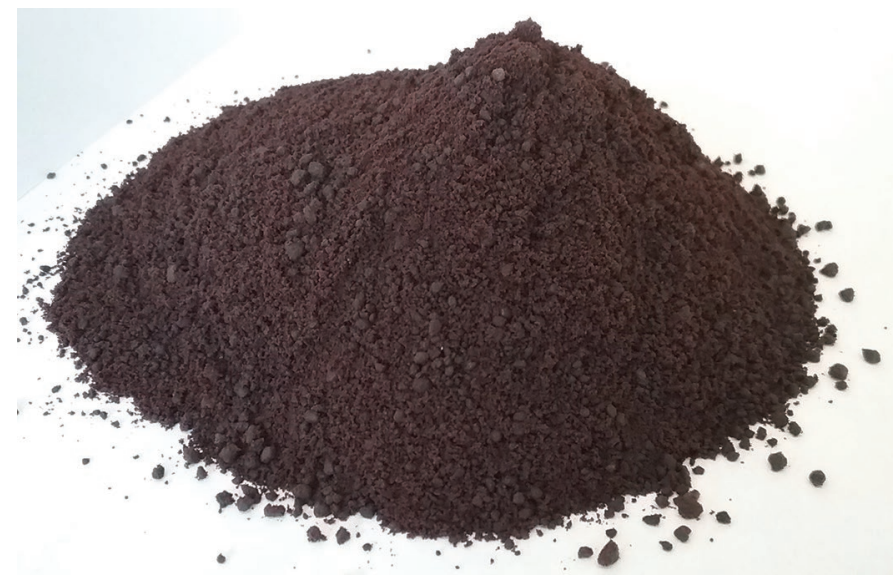

Figure 1. Proprietary high-protein corn product fed to lactating Holstein cows as the sole protein concentrate source in the present study, demonstrating a dark color likely indicative of Maillard product formation.

warranted before determining whether the HPCP in this study is a feasible protein supplement for lactating dairy cows.

Milk protein concentration in this study was greater for cows fed SBM compared with HPCP. Milk protein concentration of milk is not driven by dietary $\mathrm{CP}$ concentration (NRC, 2001; Colmenero and Broderick, 2006a), but rather milk protein content increases as metabolizable EAA supply increases, at least until requirements are met (NRC, 2001). In the present study, dietary CP concentration was the same across diets, and all were formulated to meet lysine and methionine requirements using synthetic rumen-protected AA. The reduction in milk protein content of cows fed HPCP compared with SBM points to decreased protein quality in HPCP, especially considering the lower RUP concentration for SBM.

The supply of metabolizable protein to the cow is important for maximizing milk production, and the SBMBP and CANBP diets increased milk yield and fat-corrected milk yield compared with SBM. Similar results have been noted by others who have increased RUP content in the diet (Zanton et al., 2013), although the work of Zanton et al. (2013) did not influence DMI despite the increase in milk yield, in contrast with our study. Additionally, Broderick et al. (2009) fed greater RUP concentration, which increased fat-corrected milk through increased milk fat concentration, despite no difference in milk yield or DMI. Maintaining the correct balance of RDP and RUP is important to maximize microbial protein yield to achieve optimum milk production (Santos et al., 1998), which may explain a lack of effect of increasing RUP at constant CP concentration on milk yield in other instances (Colmenero and
Broderick, 2006b). The SBM diet was formulated to meet the Met and Lys requirements of the cow, but total MP supply was still only $95 \%$ of the requirement (data not shown), indicating that there may have been a lack of metabolizable protein to achieve the milk production of the SBMBP and CANBP diets, where the cow's predicted MP requirements were met.

Many studies have been conducted evaluating canola meal supplementation compared with soybean meal. Results have largely indicated similar performance (Sánchez and Claypool, 1983; Oba et al., 2010; Paula et al., 2018) or an increase in DMI and milk production among cows fed canola meal (Broderick et al., 2015; Gidlund et al., 2015). In this study, SBMBP and CAN$\mathrm{BP}$ resulted in similar DMI, milk production, FCM and milk component yields, and nitrogen excretion. The only difference occurred in MUN concentration, which was greater for SBMBP than CANBP, corresponding with the data of Maxin et al. (2013), Martineau et al. (2014), and Paula et al. (2018). The meta-analysis by Martineau et al. (2014) noted that concentrations of blood AA, including essential and branched-chain AA, increase with canola meal supplementation. Although we did not measure blood AA concentrations in this study, other work has demonstrated that infusing a combination of methionine, lysine, and branched-chain AA decreased MUN without altering $\mathrm{N}$ efficiency (Appuhamy et al., 2011), suggesting that the canola meal in our study may have been utilized more extensively for protein synthesis. This work, combined with previous evidence mentioned earlier, reinforces the importance and interchangeability of these protein sources in dairy diets as market conditions fluctuate.

Increasing diet complexity by incorporating feeds from different plant sources may provide a more complete AA profile for the animal to enhance production. Weiss (2019) fed a diet based only on corn or a diet with other forage and protein concentrate types, and noted reduced milk production despite methionine and lysine supplementation and a similar RUP concentration, suggesting that AA other than Met and Lys may have been limiting. In contrast, adding additional protein supplement types to the diet, compared with a corn-based diet including distillers grains as a protein source, did not enhance performance in a different study (Liu et al., 2000). In the present study, the SBMBP and CANBP had more variety of ingredients than the mostly corn-based HPCP. An additional limiting AA from a single feed source may also have contributed to the reduced milk yield; however, the poor digestibility of the HPCP compared with the other treatments likely remains the primary cause.

The production process for the HPCP used in this study is proprietary; nonetheless, it is worthwhile to 
Table 7. Composition of high-protein corn products reported in the literature for comparison to the current novel and proprietary product (HPCP) used in this experiment

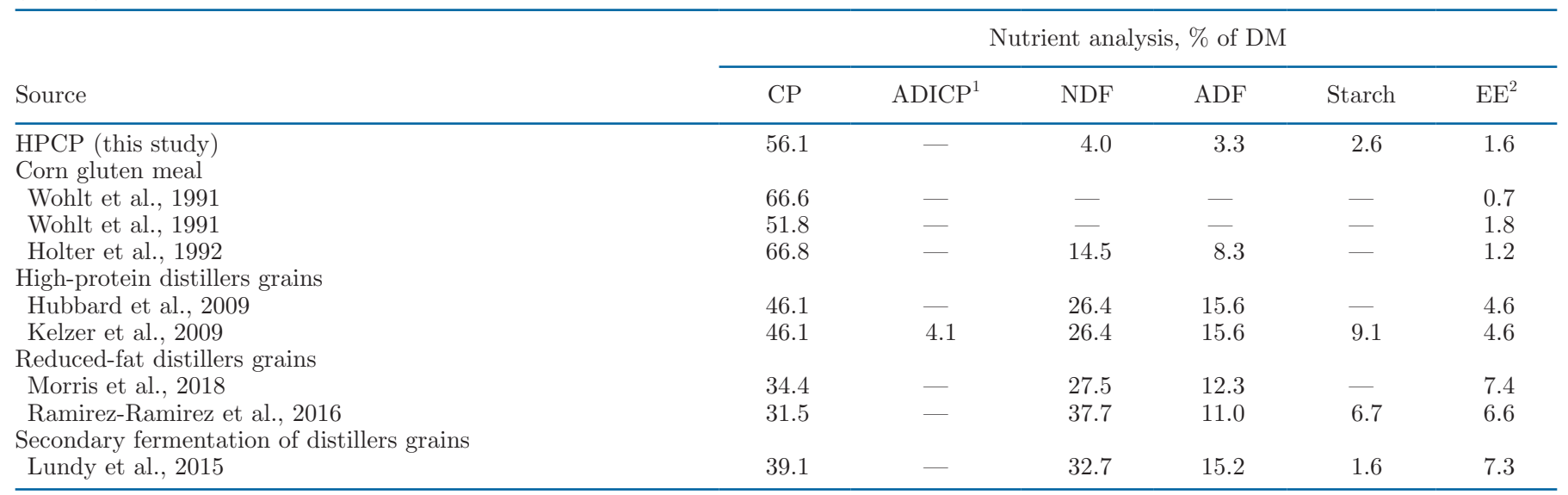

${ }^{1} \mathrm{ADICP}=$ acid-detergent insoluble crude protein.

${ }^{2} \mathrm{EE}=$ ether extract.

compare performance of this product with that of other high-protein corn products. In contrast to the present study, feeding a high-protein, corn-based dried distillers grains with solubles, resulting from fractionation before fermentation, that was approximately $44 \% \mathrm{CP}$ and $3.4 \%$ fat, failed to elicit a response in DMI, milk yield, ECM yield (Kelzer et al., 2009; Christen et al., 2010), or FCM yield (Kelzer et al., 2009). In the case of Hubbard et al. (2009), a high-protein corn product increased milk and FCM yields, and a high-protein distillers grain corn product decreased milk protein concentration in another case (Kelzer et al., 2009). Reduced-fat distillers grains maintained (Castillo-Lopez et al., 2014; Morris et al., 2018) or increased milk yield (Ramirez-Ramirez et al., 2016) but decreased 3.5\% FCM, fat, and protein yields in a more recent study (Morris et al., 2018). Cows fed a diet with corn gluten meal as the primary protein source, compared with soybean meal, produced similar quantities of milk and FCM but produced less milk protein in early lactation (Wohlt et al., 1991). Beef cattle fed a high-protein corn product $(39.1 \% \mathrm{CP})$ from secondary cellulosic ethanol fermentation of DGS had similar outcomes relative to a traditional dried distillers grains with solubles $(34.1 \% \mathrm{CP})$ for final body weight and hot carcass weight but decreased back fat thickness (Lundy et al., 2015). Chemical compositions of various high-protein corn products fed to livestock are summarized in Table 7 for comparison purposes.

Investigations into the ruminal degradation parameters of high-protein corn products have demonstrated variable results. A high-protein distillers grain product from corn fractionation increased the RUP content of the supplement compared with both soybean meal and canola meal (Maxin et al., 2013), but no evidence of differences in total-tract digestibility of DM, NDF, or CP was found in the study of Kelzer et al. (2009), in contrast with the present study. When evaluating ruminal fermentation profiles, the only effect of a highprotein corn product was a decrease of ruminal acetate concentration compared with soybean meal (Kelzer et al., 2009) or a decrease in isobutyrate concentration (Christen et al., 2010). Ruminal ammonia concentration was not affected in either instance, suggesting similar CP degradability (Kelzer et al., 2009; Christen et al., 2010). Corn gluten meal has lesser ruminal degradability compared with soybean meal (Koeln and Paterson, 1986; Annexstad et al., 1987). Although ruminal fermentation profiles were not obtained in this study, the total-tract digestibility of the HPCP was clearly decreased, as indicated by the increase in fecal $\mathrm{N}$ excretion and decrease in urine $\mathrm{N}$ excretion, and ruminal degradability was most likely decreased as well.

\section{CONCLUSIONS}

Cows fed the HPCP diet produced less milk and milk components. Cows fed HPCP consumed less CP and had lower apparent total-tract and CP digestibility, suggesting that the production process may have resulted in Maillard product formation, measured as ADICP. The SBMBP and CANBP diets performed similarly when balanced for methionine and lysine supply, supporting previous data demonstrating canola meal as a valuable substitute for soybean mean. Further efforts to improve protein quality from this HPCP are warranted.

\section{ACKNOWLEDGMENTS}

Contribution no. 20-059-J from the Kansas Agricultural Experiment Station (Manhattan, KS) with sup- 
port through Hatch project 1018048 from the USDA National Institute of Food and Agriculture (Washington, DC). The authors thank student workers at the Kansas State University Dairy Teaching and Research Center (Manhattan, KS), who spent many hours feeding and caring for the cows. The authors declare no conflicts of interest relative to this work.

\section{REFERENCES}

Annexstad, R. J., M. D. Stern, D. E. Otterby, J. G. Linn, and W. P. Hansen. 1987. Extruded soybeans and corn gluten meal as supplemental protein sources for lactating dairy cattle. J. Dairy Sci. 70:814-822. https://doi.org/10.3168/jds.S0022-0302(87)80078-4.

AOAC International. 2016. Official Methods of Analysis. 20th ed. AOAC International, Gaithersburg, MD.

Appuhamy, J. A. D. R. N., J. R. Knapp, O. Becvar, J. Escobar, and M. D. Hanigan. 2011. Effects of jugular-infused lysine, methionine, and branched-chain amino acids on milk protein synthesis in highproducing dairy cows. J. Dairy Sci. 94:1952-1960. https://doi.org/ 10.3168/jds.2010-3442.

Belyea, R. L., K. D. Rausch, and M. E. Tumbleson. 2004. Composition of corn and distillers dried grains with solubles from dry grind ethanol processing. Bioresour. Technol. 94:293-298. https://doi .org/10.1016/j.biortech.2004.01.001.

Brito, A. F., and G. A. Broderick. 2007. Effects of different protein supplements on milk production and nutrient utilization in lactating dairy cows. J. Dairy Sci. 90:1816-1827. https://doi.org/10 $.3168 /$ jds.2006-558.

Broderick, G. A., A. P. Faciola, and L. E. Armentano. 2015. Replacing dietary soybean meal with canola meal improves production and efficiency of lactating dairy cows. J. Dairy Sci. 98:5672-5687. https://doi.org/10.3168/jds.2015-9563.

Broderick, G. A., M. J. Stevenson, and R. A. Patton. 2009. Effect of dietary protein concentration and degradability on response to rumen-protected methionine in lactating dairy cows. J. Dairy Sci. 92:2719-2728. https://doi.org/10.3168/jds.2008-1277.

Calsamiglia, S., and M. Stern. 1995. A three-step in vitro procedure for estimating intestinal digestion of protein in ruminants. J. Anim. Sci. 73:1459-1465. https://doi.org/10.2527/1995.7351459x.

Castillo-Lopez, E., H. A. Ramirez Ramirez, T. J. Klopfenstein, D. Hostetler, K. Karges, S. C. Fernando, and P. J. Kononoff. 2014. Ration formulations containing reduced-fat dried distillers grains with solubles and their effect on lactation performance, rumen fermentation, and intestinal flow of microbial nitrogen in Holstein cows. J. Dairy Sci. 97:1578-1593. https://doi.org/10.3168/jds.2013 $-6865$.

Christen, K. A., D. J. Schingoethe, K. F. Kalscheur, A. R. Hippen, K. K. Karges, and M. L. Gibson. 2010. Response of lactating dairy cows to high protein distillers grains or 3 other protein supplements. J. Dairy Sci. 93:2095-2104. https://doi.org/10.3168/jds .2009-2687.

Cochran, R.C., and M.L. Galyean. 1994. Measurement of in vivo forage digestion by ruminants. Forage Qual. Eval. Util. 613-643.

Colmenero, J. J., and G. A. Broderick. 2006a. Effect of dietary crude protein concentration on milk production and nitrogen utilization in lactating dairy cows. J. Dairy Sci. 89:1704-1712. https://doi .org/10.3168/jds.S0022-0302(06)72238-X.

Colmenero, J. J., and G. A. Broderick. 2006b. Effect of amount and ruminal degradability of soybean meal protein on performance of lactating dairy cows. J. Dairy Sci. 89:1635-1643. https://doi.org/ 10.3168/jds.S0022-0302(06)72230-5.

Corredor, D. Y., S. R. Bean, T. Schober, and D. Wang. 2006. Effect of decorticating sorghum on ethanol production and composition of DDGS. Cereal Chem. 83:17-21. https://doi.org/10.1094/CC-83 -0017 .

Donkin, S. S., G. A. Varga, T. F. Sweeney, and L. D. Muller. 1989. Rumen-protected methionine and lysine: Effects on animal perfor- mance, milk protein yield, and physiological measures. J. Dairy Sci. 72:1484-1491. https://doi.org/10.3168/jds.S0022-0302(89)79258 -4 .

Gidlund, H., M. Hetta, S. J. Krizsan, S. Lemosquet, and P. Huhtanen. 2015. Effects of soybean meal or canola meal on milk production and methane emissions in lactating dairy cows fed grass silagebased diets. J. Dairy Sci. 98:8093-8106. https://doi.org/10.3168/ jds.2015-9757.

Goering, H. K., and P. J. Van Soest. 1970. Forage Fiber Analysis (Apparatus, Reagents, Procedures, and Some Applications). Agriculture Handbook No. 379. Agricultural Research Service, USDA, Washington, DC.

Holter, J. B., H. H. Hayes, W. E. Urban Jr., S. Ramsey, and H. Rideout. 1992. Response of Holstein cows to corn gluten meal used to increase undegradable protein in early or later lactation. J. Dairy Sci. 75:1495-1506. https://doi.org/10.3168/jds.S0022 -0302(92)77906-5.

Hubbard, K. J., P. J. Kononoff, A. M. Gehman, J. M. Kelzer, K. Karges, and M. L. Gibson. 2009. Short communication: The effect of feeding high protein distillers dried grains on milk production of Holstein cows. J. Dairy Sci. 92:2911-2914. https://doi.org/10 $.3168 /$ jds.2008-1955.

Kelzer, J. M., P. J. Kononoff, A. M. Gehman, L. O. Tedeschi, K. Karges, and M. L. Gibson. 2009. Effects of feeding three types of corn-milling coproducts on milk production and ruminal fermentation of lactating Holstein cattle. J. Dairy Sci. 92:5120-5132. https: //doi.org/10.3168/jds.2009-2208.

Kelzer, J. M., P. J. Kononoff, L. O. Tedeschi, T. C. Jenkins, K. Karges, and M. L. Gibson. 2010. Evaluation of protein fractionation and ruminal and intestinal digestibility of corn milling co-products. J. Dairy Sci. 93:2803-2815. https://doi.org/10.3168/jds.2009-2460.

Kim, Y., R. Hendrickson, N. Mosier, M. Ladisch, B. Bals, V. Balan, and B. E. Dale. 2008. Enzyme hydrolysis and ethanol fermentation of liquid hot water and AFEX pretreated distillers' grains at highsolids loadings. Bioresour. Technol. 99:5206-5215. https://doi.org/ 10.1016/j.biortech.2007.09.031.

Kim, Y., R. Hendrickson, N. S. Mosier, M. R. Ladisch, B. Bals, V. Balan, B. E. Dale, B. S. Dien, and M. A. Cotta. 2010. Effect of compositional variability of distillers' grains on cellulosic ethanol production. Bioresour. Technol. 101:5385-5393. https://doi.org/10 .1016/j.biortech.2010.02.054.

Klopfenstein, T. J., G. E. Erickson, and V. R. Bremer. 2008. Boardinvited review: Use of distillers by-products in the beef cattle feeding industry. J. Anim. Sci. 86:1223-1231. https://doi.org/10.2527/ jas.2007-0550.

Koeln, L. L., and J. A. Paterson. 1986. Nitrogen balance and amino acid disappearance from the small intestine in calves fed soybean meal-, toasted soybean meal- or corn gluten meal-supplemented diets. J. Anim. Sci. 63:1258-1266. https://doi.org/10.2527/jas1986 .6341258x.

Kononoff, P. J., and K. J. Hanford. 2006. Technical note: Estimating statistical power of mixed models used in dairy nutrition experiments. J. Dairy Sci. 89:3968-3971. https://doi.org/10.3168/jds .S0022-0302(06)72439-0.

Krishnamoorthy, U., C. J. Sniffen, M. D. Stern, and P. J. Van Soest. 1983. Evaluation of a mathematical model of rumen digestion and an in vitro simulation of rumen proteolysis to estimate the rumenundegraded nitrogen content of feedstuffs. Br. J. Nutr. 50:555-568. https://doi.org/10.1079/BJN19830127.

Lardy, G. P., and M. S. Kerley. 1994. Effect of increasing the dietary level of rapeseed meal on intake by growing beef steers. J. Anim. Sci. 72:1936-1942. https://doi.org/10.2527/1994.7281936x.

Liu, C., D. J. Schingoethe, and G. A. Stegeman. 2000. Corn distillers grains versus a blend of protein supplements with or without ruminally protected amino acids for lactating cows. J. Dairy Sci. 83:2075-2084. https://doi.org/10.3168/jds.S0022-0302(00)75089 -2 .

Liu, K. 2011. Chemical composition of distillers grains, A review. J. Agric. Food Chem. 59:1508-1526. https://doi.org/10.1021/ jf103512z. 
Loy, D. D., and E. L. Lundy. 2019. Nutritional properties and feeding value of corn and its coproducts. Pages 633-659 in Corn: Chemistry and Technology. S. O. Serna-Saldivar, ed. Elsevier, Amsterdam, the Netherlands. https://doi.org/10.1016/b978-0-12-811971 $-6.00023-1$.

Lundy, E. L., D. D. Loy, and S. L. Hansen. 2015. Influence of distillers grains resulting from a cellulosic ethanol process utilizing corn kernel fiber on nutrient digestibility of lambs and steer feedlot performance. J. Anim. Sci. 93:2265-2274. https://doi.org/10.2527/jas .2014-8572.

Martineau, R., D. Ouellet, and H. Lapierre. 2014. The effect of feeding canola meal on concentrations of plasma amino acids. J. Dairy Sci. 97:1603-1610. https://doi.org/10.3168/jds.2013-7125.

Maxin, G., D. R. Ouellet, and H. Lapierre. 2013. Ruminal degradability of dry matter, crude protein, and amino acids in soybean meal, canola meal, corn, and wheat dried distillers grains. J. Dairy Sci. 96:5151-5160. https://doi.org/10.3168/jds.2012-6392.

Mikulski, D., and G. Kłosowski. 2018. Efficiency of dilute sulfuric acid pretreatment of distillery stillage in the production of cellulosic ethanol. Bioresour. Technol. 268:424-433. https://doi.org/ 10.1016/j.biortech.2018.08.005.

Miller-Cushon, E. K., and T. J. DeVries. 2017. Feed sorting in dairy cattle: Causes, consequences, and management. J. Dairy Sci. 100:4172-4183. https://doi.org/10.3168/jds.2016-11983.

Morris, D. L., S. H. Kim, P. J. Kononoff, and C. Lee. 2018. Continuous 11-week feeding of reduced-fat distillers grains with and without monensin reduces lactation performance of dairy cows. J. Dairy Sci. 101:5971-5983. https://doi.org/10.3168/jds.2017-14170.

Mulrooney, C. N., D. J. Schingoethe, K. F. Kalscheur, and A. R. Hippen. 2009. Canola meal replacing distillers grains with solubles for lactating dairy cows. J. Dairy Sci. 92:5669-5676. https://doi.org/ 10.3168/jds.2009-2276.

Nichols, J. R., D. J. Schingoethe, H. A. Maiga, M. J. Brouk, and M. S. Piepenbrink. 1998. Evaluation of corn distillers grains and ruminally protected lysine and methionine for lactating dairy cows. J. Dairy Sci. 81:482-491. https://doi.org/10.3168/jds.S0022 $-0302(98) 75600-0$.

Noftsger, S., and N. R. St-Pierre. 2003. Supplementation of methionine and selection of highly digestible rumen undegradable protein to improve nitrogen efficiency for milk production. J. Dairy Sci. 86:958-969. https://doi.org/10.3168/jds.S0022-0302(03)73679-0.

NRC (National Research Council). 2001. Nutrient Requirements of Dairy Cattle. 7th rev. ed. National Academy Press, Washington, DC.

Oba, M., G. B. Penner, T. D. Whyte, and K. Wierenga. 2010. Effects of feeding triticale dried distillers grains plus solubles as a nitrogen source on productivity of lactating dairy cows. J. Dairy Sci. 93:2044-2052. https://doi.org/10.3168/jds.2009-2454.

Paula, E. M., G. A. Broderick, M. A. C. Danes, N. E. Lobos, G. I. Zanton, and A. P. Faciola. 2018. Effects of replacing soybean meal with canola meal or treated canola meal on ruminal digestion, omasal nutrient flow, and performance in lactating dairy cows. J. Dairy Sci. 101:328-339. https://doi.org/10.3168/jds.2017-13392.

Raffrenato, E., D. A. Ross, and M. E. Van Amburgh. 2018. Development of an in vitro method to determine rumen undigested aNDFom for use in feed evaluation. J. Dairy Sci. 101:9888-9900. https: //doi.org/10.3168/jds.2018-15101.

Ramirez-Ramirez, H. A., E. Castillo Lopez, C. J. R. Jenkins, N. D. Aluthge, C. Anderson, S. C. Fernando, K. J. Harvatine, and P. J. Kononoff. 2016. Reduced-fat dried distillers grains with solubles reduces the risk for milk fat depression and supports milk production and ruminal fermentation in dairy cows. J. Dairy Sci. 99:1912-1928. https://doi.org/10.3168/jds.2015-9712.

Robinson, P. H., K. Karges, and M. L. Gibson. 2008. Nutritional evaluation of four co-product feedstuffs from the motor fuel ethanol distillation industry in the Midwestern USA. Anim. Feed Sci. Technol. 146:345-352. https://doi.org/10.1016/j.anifeedsci.2008 .01 .004 .
Ross, D. A., M. Gutierrez-Botero, and M. E. Van Amburgh. 2013. Development of an in vitro intestinal digestibility assay for ruminant feeds. Pages 190-202 in Cornell Nutrition Conference. Cornell University, East Syracuse, NY.

Sánchez, J. M., and D. W. Claypool. 1983. Canola meal as a protein supplement in dairy rations. J. Dairy Sci. 66:80-85. https://doi .org/10.3168/jds.S0022-0302(83)81756-1.

Santos, F. A. P., J. E. P. Santos, C. B. Theurer, and J. T. Huber. 1998. Effects of rumen-undegradable protein on dairy cow performance: A 12-year literature review. J. Dairy Sci. 81:3182-3213. https://doi .org/10.3168/jds.S0022-0302(98)75884-9.

Schingoethe, D. J., K. F. Kalscheur, A. R. Hippen, and A. D. Garcia. 2009. Invited review: The use of distillers products in dairy cattle diets. J. Dairy Sci. 92:5802-5813. https://doi.org/10.3168/ jds.2009-2549.

Shreve, B., N. Thiex, and M. Wolf. 2006. NFTA Method 2.1.4-Dry matter by oven drying for $3 \mathrm{hr}$ at 105C. National Forage Testing Association, Lincoln, NE.

Srinivasan, R., R. A. Moreau, K. D. Rausch, R. L. Belyea, M. E. Tumbleson, and V. Singh. 2005. Separation of fiber from distillers dried grains with solubles (DDGS) using sieving and elutriation. Cereal Chem. 82:528-533. https://doi.org/10.1094/CC-82-0528.

Urriola, P. E., L. J. Johnston, H. H. Stein, and G. C. Shurson. 2013. Prediction of the concentration of standardized ileal digestible amino acids in distillers dried grains with solubles. J. Anim. Sci. 91:4389-4396. https://doi.org/10.2527/jas.2013-6362.

Valadares, R. F. D., G. A. Broderick, S. C. Valadares Filho, and M. K. Clayton. 1999. Effect of replacing alfalfa silage with high moisture corn on ruminal protein synthesis estimated from excretion of total purine derivatives. J. Dairy Sci. 82:2686-2696. https://doi.org/10 .3168/jds.S0022-0302(99)75525-6.

van Soest, P. J., and V. C. Mason. 1991. The influence of the Maillard reaction upon the nutritive value of fibrous feeds. Anim. Feed Sci. Technol. 32:45-53. https://doi.org/10.1016/0377-8401(91)90008 $-\mathrm{G}$.

Wang, C., H. Y. Liu, Y. M. Wang, Z. Q. Yang, J. X. Liu, Y. M. Wu, T. Yan, and H. W. Ye. 2010. Effects of dietary supplementation of methionine and lysine on milk production and nitrogen utilization in dairy cows. J. Dairy Sci. 93:3661-3670. https://doi.org/10 $.3168 /$ jds.2009-2750.

Wang, L., C. L. Weller, V. L. Schlegel, T. P. Carr, and S. L. Cuppett. 2007. Comparison of supercritical $\mathrm{CO}_{2}$ and hexane extraction of lipids from sorghum distillers grains. Eur. J. Lipid Sci. Technol. 109:567-574. https://doi.org/10.1002/ejlt.200700018.

Weiss, W. P. 2019. Effects of feeding diets composed of corn silage and a corn milling product with and without supplemental lysine and methionine to dairy cows. J. Dairy Sci. 102:2075-2084. https://doi .org/10.3168/jds.2018-15535.

White, J. S., B. K. Yohannan, and G. M. Walker. 2008. Bioconversion of brewer's spent grains to bioethanol. FEMS Yeast Res. 8:11751184. https://doi.org/10.1111/j.1567-1364.2008.00390.x.

Wohlt, J. E., S. L. Chmiel, P. K. Zajac, L. Backer, D. B. Blethen, and J. L. Evans. 1991. Dry matter intake, milk yield and composition, and nitrogen use in Holstein cows fed soybean, fish, or corn gluten meals. J. Dairy Sci. 74:1609-1622. https://doi.org/10.3168/jds .S0022-0302(91)78323-9.

Zanton, G. I., A. J. Heinrichs, and C. M. Jones. 2013. Short communication: Effects of level of rumen-degradable protein and corn distillers grains in corn silage-based diets on milk production and ruminal fermentation in lactating dairy cows1. J. Dairy Sci. 96:4638-4642. https://doi.org/10.3168/jds.2012-6030.

\section{ORCIDS}

B. J. Bradford ๑ https://orcid.org/0000-0002-6775-4961 